\title{
Microwave-promoted synthesis of chiral pyridinium salts
}

\author{
Gustavo H. R. Viana, ${ }^{\mathrm{a}}$ Itamar C. Santos, ${ }^{\mathrm{a}}$ Rosemeire B. Alves, ${ }^{\mathrm{a}}$ Laurent Gil, ${ }^{\mathrm{b}}$ \\ Christian Marazano ${ }^{\mathrm{c}}$ and Rossimiriam P. F. Gil ${ }^{\mathrm{a}, *}$ \\ ${ }^{a}$ Departamento de Química, Instituto de Ciências Exatas, Universidade Federal de Minas Gerais, Av. Antônio Carlos, \\ 6627, 31270-901 Belo Horizonte, Brazil \\ ${ }^{\mathrm{b}}$ Departamento de Química, ICEB, UFOP, Campus Morro do Cruzeiro, Ouro Preto, MG, Brazil \\ ${ }^{\mathrm{c}}$ Institut de Chimie des Substances Naturelles, Avenue de la Terrasse, 91198 Gif-sur-Yvette, France
}

Received 7 July 2005; revised 5 September 2005; accepted 7 September 2005

Available online 23 September 2005

\begin{abstract}
The synthesis of several chiral pyridinium salts via Zincke's reaction can be easily accomplished by domestic microwave oven irradiation. Yield enhancements, reduction of reaction time, and less racemization were observed under microwave heating when compared to conventional heating in similar conditions.

(C) 2005 Elsevier Ltd. All rights reserved.
\end{abstract}

Pyridinium salts are a versatile class of compounds used as phase transfer catalysts, ${ }^{1}$ initiators of cationic polymerization, ${ }^{2}$ wide range antimicrobials, ${ }^{3}$ enzyme inhibitors, ${ }^{4}$ acylating agents, ${ }^{5}$ dyes, and cationic surfactants. ${ }^{6}$ Their chiral representatives, that is, pyridinium salts containing a chiral auxiliary group linked to the ring nitrogen, have been largely used as starting materials in asymmetric synthesis to obtain substituted chiral dihydropyridines, ${ }^{7}$ tetrahydropyridines, ${ }^{8}$ piperidines, ${ }^{9}$ and nitrogenated complex compounds such as natural alkaloids ${ }^{10}$ and synthetic candidates for drugs. ${ }^{4 b}$

Several synthesis routes for pyridinium salts are known, but the most commonly used one is the Menschutkin reaction, a $\mathrm{S}_{\mathrm{N}} 2$ reaction of a pyridine derivative with an organic halide or sulfonate. ${ }^{6}$ Nevertheless, this method in not suitable to prepare chiral pyridinium salts with a stereocenter directly attached to the ring nitrogen since there is a significant risk of racemization by a competing $\mathrm{S}_{\mathrm{N}} 1$ process. There are two main methods to obtain these kinds of salts with negligible racemization. The first uses pyrilium salts ${ }^{11,12}$ and the second employs Zincke's salts, ${ }^{13}$ a highly electrophilic species formed by reaction between a pyridine derivative and 1-chloro-2,4-dinitrobenzene.

Keywords: Asymmetric synthesis; Amino alcohols; Pyridines; Microwave irradiation; Zincke's reaction.

* Corresponding author. Tel.: +55 3134995721; fax: +55

3134995700; e-mail: rossi@netuno.lcc.ufmg.br
The original Zincke's reaction ${ }^{14}$ involves the attack of a primary amine 1 on Zincke's salt 2 (Eq. 1) to produce salt 3. As the mechanism of reaction does not involve rupture of the $\mathrm{C}-\mathrm{N}$ bond, if we use a primary chiral amine, the configuration of the stereocenter will be kept. This idea was extensively studied by Marazano ${ }^{15}$ and Zincke's reaction became an excellent method for the synthesis of chiral pyridinium salts.

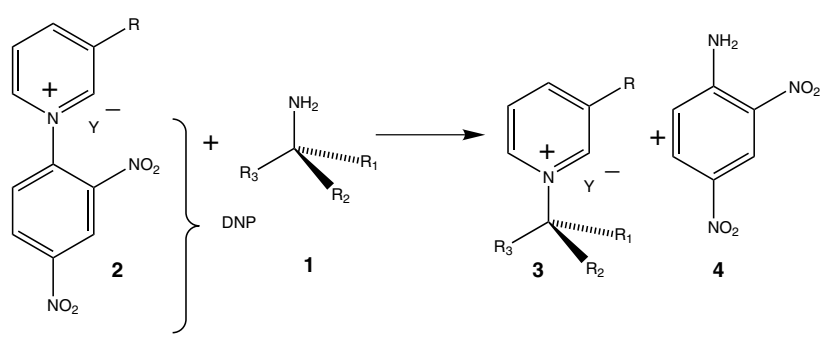

Some recent uses of Zincke's reaction have been described by Eda and co-workers ${ }^{4 \mathrm{a}, 16}$ and Urban et al. ${ }^{17}$ The former adapted this reaction for solid-phase application to achieve chiral quaternary ammonium salts analogs of vesamicol ${ }^{4 a}$ and salts that could be useful to treat cystic fribosis. ${ }^{16}$ The latter applied Zincke's reaction to make chiral naphthyridinium salts for the synthesis of cytotoxic alkaloid manzamine A. ${ }^{17}$ 
Faster and simpler methods are a permanent need in organic synthesis. In 1986, Gedye ${ }^{18}$ and Giguere ${ }^{19}$ demonstrated that many organic reactions could be rapidly conducted under microwave irradiation. Since then, microwave irradiation has been increasingly used as a laboratory method to accelerate synthesis. ${ }^{20}$ Microwave-assisted organic synthesis has several advantages over conventional methodology: remarkable reduction of reaction time (up to three orders of magnitude), improved isolated product yields (when thermal decomposition is associated with conventional heating reactions), and sometimes, effects on chemo-, regio-, and stereoselectivities are also achieved. ${ }^{21}$

Due to the important role of chiral pyridinium salts in asymmetric synthesis and the absence of reported microwave-assisted Zincke's reaction, we report here a new and efficient method for the fast synthesis of chiral pyridinium salts from chiral primary amines.
We have used a modified domestic microwave oven, 2450-MHz General Electric JEI 1145 AWA. The oven top was cut to accommodate a reflux condenser and a steel ring was used to avoid microwave leakage. The turnable dish was turned off.

A typical procedure involves irradiation of a mixture of 1 equiv of Zincke's salt and 1 equiv of primary amine using $10 \mathrm{~mL}$ of 1-butanol as solvent under microwave irradiation for 5-10 min. In the end of the reaction, the salt recovery by simple partition into water phase from ethyl acetate allowed its complete separation from 2,4-dinitroaniline 4 (Eq. 1). Purification of the crude products by silica gel flash chromatography furnished the isolated salts with yields from $61 \%$ to $100 \%$ (Table 1). All salts were confirmed by ${ }^{1} \mathrm{H}$ NMR and ${ }^{13} \mathrm{C}$ NMR analyses. ${ }^{22}$ All reactions were performed under microwave and conventional heating for comparison. The results are presented in Table 1.

Table 1. Synthesis of pyridinium salts under microwave and conventional heating

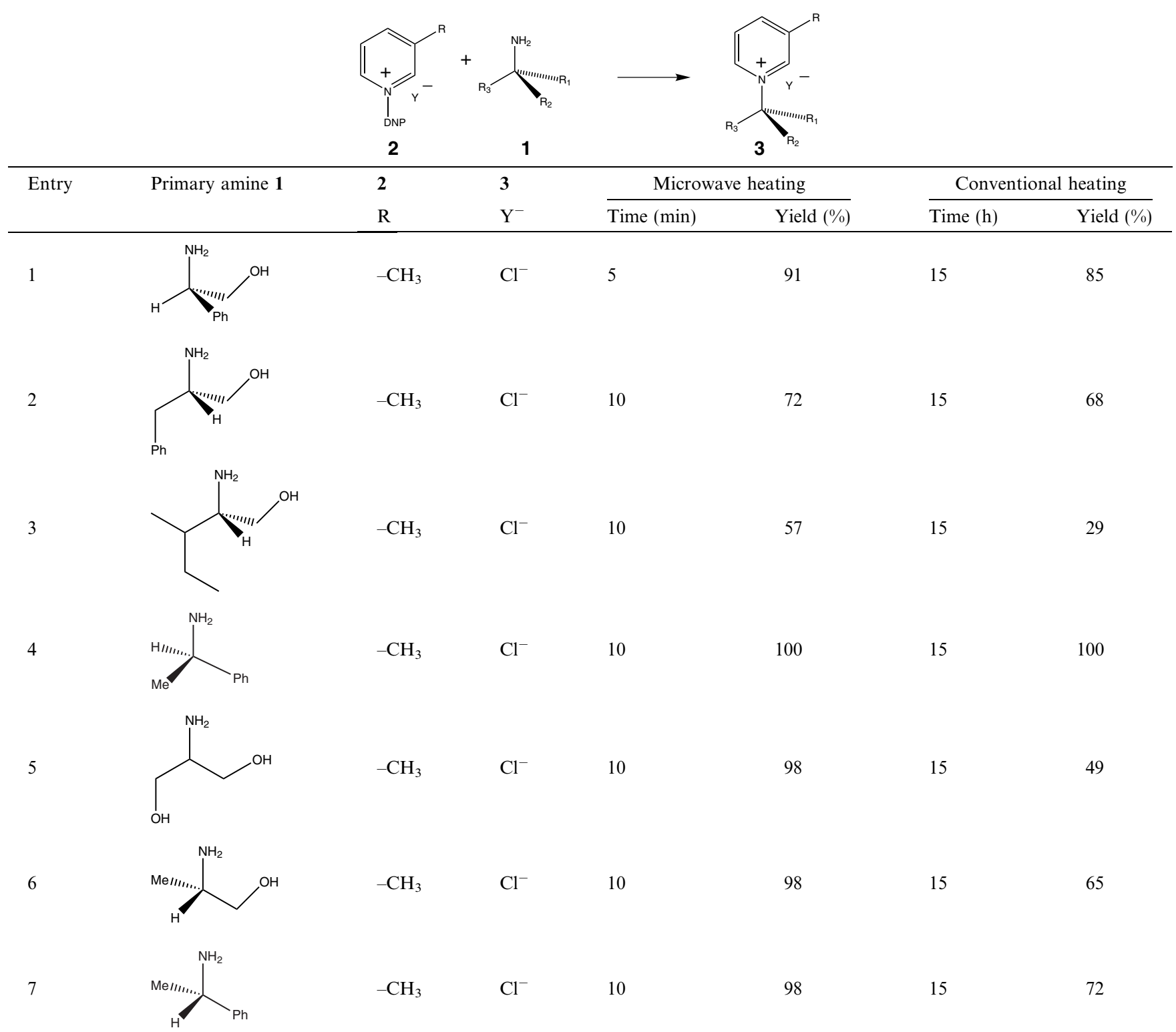


Table 1 (continued)

\begin{tabular}{|c|c|c|c|c|c|c|c|}
\hline \multirow[t]{2}{*}{ Entry } & \multirow[t]{2}{*}{ Primary amine 1} & \multirow{2}{*}{$\begin{array}{l}2 \\
\mathrm{R} \\
\end{array}$} & \multirow{2}{*}{$\begin{array}{l}3 \\
\mathrm{Y}^{-}\end{array}$} & \multicolumn{2}{|c|}{ Microwave heating } & \multicolumn{2}{|c|}{ Conventional heating } \\
\hline & & & & Time (min) & Yield $(\%)$ & Time (h) & Yield $(\%)$ \\
\hline 8 & & $-\mathrm{H}$ & $\operatorname{SDS}^{\mathrm{a}}$ & 10 & 61 & 15 & 48 \\
\hline 9 & & $-\mathrm{H}$ & $\mathrm{Cl}^{-}$ & 10 & 67 & 15 & 70 \\
\hline 10 & & $-\mathrm{H}$ & $\mathrm{Cl}^{-}$ & 10 & 93 & 15 & 92 \\
\hline 11 & & Ethyl & $\mathrm{Cl}^{-}$ & 10 & 86 & 15 & 75 \\
\hline
\end{tabular}

${ }^{\mathrm{a}} \mathrm{SDS}=$ dodecylsulfate.

Zincke's salts were easily prepared by reaction of commercially available pyridine, 3-picoline, and 3-ethylpyridine (1 equiv of each) and 1 equiv of 1-chloro-2,4dinitrobenzene under acetone reflux for $15 \mathrm{~h}$. The selected primary amines were $(R)-(-)$-phenylglycinol, $(S)-(+)-, \quad(S)-(-)$-phenylalaninol, $(S)-(+)$-isoleucinol, $(R)-(+)$ and $(S)-(-)-\alpha-m e t h y l b e n z y l a m i n e$, and the achiral amine serinol.

From Table 1, it can be seen that the reaction time was reduced by several times under microwave irradiation when compared with reactions performed under conventional heating. Marazano established that the ideal condition for this reaction under conventional heating was 1-butanol refluxing as solvent for $15 \mathrm{~h}$. We have found similar results for conventional heating; however, for microwave heating, the reaction time is never larger than $10 \mathrm{~min}$. Furthermore, the yield of microwave heating reactions after purification was greatly increased. It is very interesting to observe that under microwave irradiation, pyridinium salts were obtained with less racemization than by the methods described until today, possibly due to the much shorter reaction times. For example, for the compound of the table entry 9 , the value of $[\alpha]_{D}^{20}$ reported for the solution conventional $\operatorname{method}^{9}$ was $-44^{\circ}$. Under solid-phase ${ }^{4 a}$ Zincke conditions, the same compound was obtained with $[\alpha]_{\mathrm{D}}^{20}-50$, and by microwave irradiation, the value recorded was $-53.4^{\circ}\left(\mathrm{CH}_{3} \mathrm{OH}\right.$, $c$ 2.95). In addition, we also report the values of $-25.9^{\circ}\left(\mathrm{CH}_{3} \mathrm{OH}, c 1.20\right)$ for the specific rotation of the compound derived from $(S)-(-)-\alpha$-methylbenzylamine (entry 7) for conventional heating and $-32.3^{\circ}\left(\mathrm{CH}_{3} \mathrm{OH}\right.$, $c$ 1.05) for microwave heating. This success led to the preparation of other chiral derivatives by microwavepromoted Zincke's reaction.

In summary, we have developed an operationally simple and efficient method for the synthesis of chiral pyridinium salts by microwave-promoted Zincke's reaction. The conditions employed furnished good yields and less racemization than by conventional heating methods. These results confirm the applicability of microwave heating to the improvement of classic reactions.

\section{Acknowledgements}

The authors thank Conselho Nacional de Desenvolvimento Científico e Tecnológico (CNPq), for the fellowship of G.H.R.V.

\section{References and notes}

1. Lucchese, A. M.; Marzorati, L. Quim. Nova. 2000, 23, $641-652$

2. Atmaca, L.; Onen, A.; Yagci, Y. Eur. Polym. J. 2001, 37, 677-682.

3. Pernak, J.; Kalewska, J.; Ksycinska, H.; Cybulski, J. Eur. J. Med. Chem. 2001, 36, 899-907.

4. (a) Eda, M.; Kurth, M. J. Tetrahedron Lett. 2001, 42, 2063-2068; (b) Palin, R.; Clark, J. K.; Cowley, P.; Muir, A. W.; Pow, E.; Prosser, A. B.; Taylor, R.; Zhang, M. Q. Bioorg. Med. Chem. Lett. 2002, 12, 2569-2572.

5. Scriven, E. F. V. Chem. Soc. Rev. 1983, 12, 129-133.

6. Pernak, J.; Rogoza, J. Arkivoc 2000, 1, 889-904.

7. Wong, Y. S.; Marazano, C.; Gnecco, D.; Das, B. C. Tetrahedron Lett. 1994, 35, 707-710.

8. Mehmandoust, M.; Marazano, C.; Das, B. C. J. Chem. Soc., Chem. Commun. 1989, 1185-1187.

9. Diez, A.; Vilaseca, L.; López, I.; Rubiralta, M.; Marazano, C.; Grierson, D. S.; Husson, H. P. Heterocycles 1991, 32, 2139-2149.

10. Comins, D. L.; Joseph, P.; Boehring, R. R. J. Am. Chem. Soc. 1994, 116, 4719-4728.

11. Katritzky, A. R.; Manzo, R. H. J. Chem. Soc., Perkin Trans. 2 1981, 571.

12. Katritzky, A. R.; Marson, C. M. Angew. Chem., Ed. Int. Engl. 1984, 23, 420-429.

13. Kost, A. N.; Gromov, S. P.; Sagitullin, R. S. Tetrahedron 1981, 37, 3423-3454.

14. Zincke, T. H.; Heuser, G.; Möller, W. Ann. Chim. 1904, 333, 296. 
15. Genisson, Y.; Marazano, C.; Mehmandoust, M.; Gnecco, D.; Das, B. C. Synlett 1992, 431-434.

16. Eda, M.; Kurth, M. J.; Nantz, M. H. J. Org. Chem. 2000, $65,5131-5135$.

17. Urban, D.; Duval, E.; Langlois, Y. Tetrahedron Lett. 2000, 41, 9251-9256.

18. Gedye, R.; Smith, F.; Westaway, K.; Ali, H.; Baldisera, L.; Laberge, L.; Rousell, J. Tetrahedron Lett. 1986, 27, 279282.

19. Giguerre, R. J.; Bray, T. L.; Duncan, S. M.; Majetich, G. Tetrahedron Lett. 1986, 27, 4945-4948.

20. Sowmya, S.; Balasubramanian, K. K. Synth. Commun. 1994, 2097.

21. Cruz, P.; Hoz, A.; Langa, F. Tetrahedron 1997, 53, 25992608.

22. A representative procedure to obtain pyridinium salts is as follows: A solution of $(S)-(-)$ - $\alpha$-methylbenzylamine
$(0.259 \mathrm{~g}, \quad 2.41 \mathrm{mmol})$ and Zincke's salt $\left(\mathrm{R}=\mathrm{CH}_{3}\right.$, $\left.\mathrm{Y}=\mathrm{Cl}^{-}\right)(0.633 \mathrm{~g}, 2.14 \mathrm{mmol})$ in 1-butanol $(10 \mathrm{~mL})$ was irradiated with microwave for $10 \mathrm{~min}$. After evaporation, the residue was solubilized in water, and to this solution was added ammonium hydroxide until $\mathrm{pH}$ 10. The next step was a simple partition in water phase from ethyl acetate. The aqueous phase was evaporated and the residue was chromatographed $\left(\mathrm{CHCl}_{3} / \mathrm{CH}_{3} \mathrm{OH} 100 / 1,94 / 6,90 / 10,83 / 17,50 / 50\right)$. Pyridinium salt (entry 7, $0.490 \mathrm{~g}, 98 \%$ ) was obtained as a yellow oil: $[\alpha]_{\mathrm{D}}^{20}-32.3\left(\mathrm{CH}_{3} \mathrm{OH}, c 1.05\right) ;{ }^{1} \mathrm{H}$ NMR $\left(\mathrm{D}_{2} \mathrm{O}\right.$, $200 \mathrm{MHz}): \delta 1.97(3 \mathrm{H}, \mathrm{t}, J=7.1 \mathrm{~Hz}) ; 2.41(3 \mathrm{H}, \mathrm{s}) ; 5.99$ $(1 \mathrm{H}, \quad \mathrm{q}, \quad J=7.0 \mathrm{~Hz}) ; 7.37-7.46(5 \mathrm{H}, \mathrm{m}) ; 7.82(1 \mathrm{H}$, t, $J=7.4 \mathrm{~Hz}) ; 8.25(1 \mathrm{H}, \mathrm{d}, J=7.9 \mathrm{~Hz}) ; 8.62-8.75(2 \mathrm{H}$, $\mathrm{m}) ;{ }^{13} \mathrm{C}$ NMR $\left(\mathrm{D}_{2} \mathrm{O}, 50 \mathrm{MHz}\right): \delta 18.09 ; 20.12 ; 70.89$; $127.82 ; 128.00 ; 129.82 ; 130.17 ; 137.37 ; 140.62 ; 142.84$; 146.85 . 